\title{
Selectively fluorinated cyclohexane building blocks: Derivatives of carbonylated all-cis-3-phenyl-1,2,4,5- tetrafluorocyclohexane
}

\author{
Mohammed Salah Ayoup ${ }^{1,2}$, David B. Cordes ${ }^{1}$, Alexandra M. Z. Slawin ${ }^{1}$ \\ and David O'Hagan*1
}

\author{
Full Research Paper \\ Address: \\ ${ }^{1}$ School of Chemistry, University of St Andrews, North Haugh, St \\ Andrews, KY16 9ST, UK and 2Department of Chemistry, Faculty of \\ Science, P.B 426 Ibrahimia, Alexandria University, Egypt \\ Email: \\ David O'Hagan* - do1@st-andrews.ac.uk \\ * Corresponding author \\ Keywords: \\ cyclohexane carbonylation; fluorine containing building blocks: \\ organofluorine chemistry
}

\author{
doi:10.3762/bjoc.11.287 \\ Received: 18 October 2015 \\ Accepted: 09 December 2015 \\ Published: 21 December 2015 \\ Associate Editor: T. P. Yoon
}

Beilstein J. Org. Chem. 2015, 11, 2671-2676.

(C) 2015 Ayoup et al; licensee Beilstein-Institut.

License and terms: see end of document.

\begin{abstract}
Palladium catalysed carbonylation reactions using the meta- and para-iodo derivatives of all-cis-3-phenyl-1,2,4,5-tetrafluorocyclohexane (4) are illustrated as the start point for a variety of functional group interconversions. The resultant benzaldehyde and benzoic acids offer novel building blocks for further derivatisation and facilitate the incorporation of the facially polarised all-cis1,2,4,5-tetrafluorocyclohexane motif into more advanced molecular scaffolds.
\end{abstract}

\section{Introduction}

Selectively fluorinated building blocks have proven invaluable in drug discovery [1] and agrochemical research programmes [2]. Most such building blocks possess aryl/heteroaryl-F, aryl/ heteroaryl- $(\mathrm{X}) \mathrm{CF}_{3}$ or variants thereof, whereas selectively fluorinated aliphatics are much rarer. We have had a focus on introducing selectively fluorinated cyclohexane rings, to complement aromatic building blocks. In this context we have recently prepared the all-cis-tetrafluorocyclohexanes $\mathbf{2}$ and $\mathbf{3}[3,4]$ and also all-cis-hexafluorocyclohexane (1) [5] as shown in Figure 1. In the case of the hexafluorocyclohexane, the ring maintains a chair conformation and therefore there are three $\mathrm{C}-\mathrm{F}$ bonds orientated triaxial, on one face of the ring. This gives rise to a large dipole moment (6.2 D) and a molecule which is among the most polar aliphatics known in organic chemistry. The all-cistetrafluorocyclohexanes $\mathbf{2}$ and $\mathbf{3}$ are also facially polarised because in the chair conformation, they always have two 1,3diaxial $\mathrm{C}-\mathrm{F}$ bonds on one face of the ring, and this results in ring systems also with large dipole moments (4.9 D for 2 and $5.2 \mathrm{D}$ for 3 ). The nature of these cyclohexanes, where the two faces are oppositely polarised, presents a unique property for 

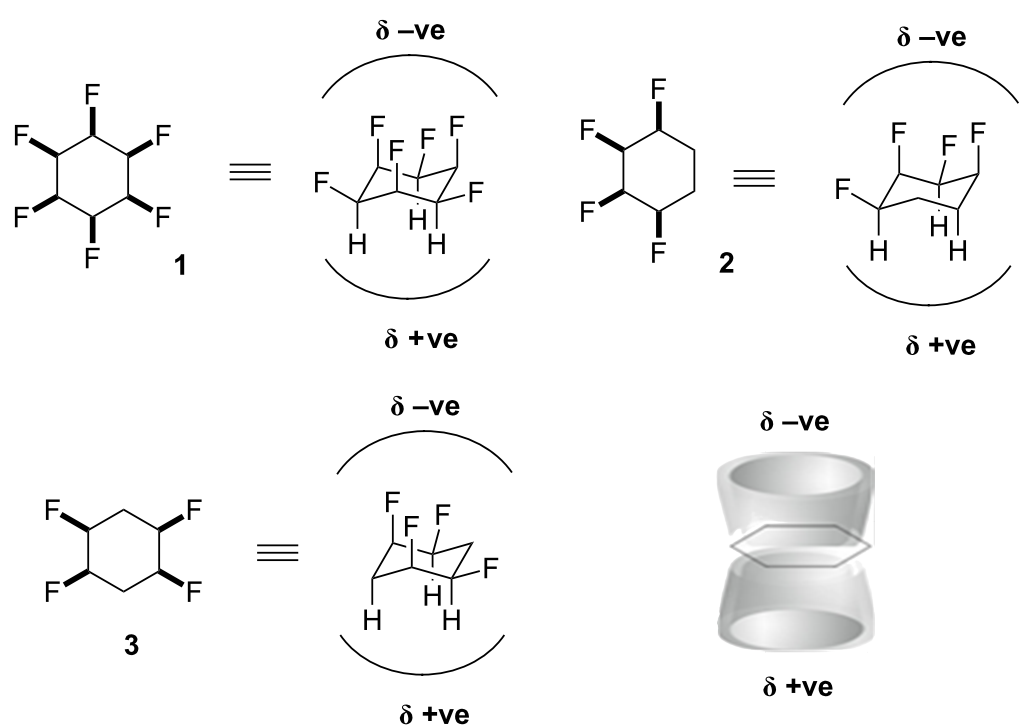

Figure 1: All cis-hexafluoro- 1 and tetrafluorocyclohexanes 2 and $\mathbf{3}$ result in facially polarised ring motifs with an electrostatically negative $(\delta-v e)$ fluorine face and an electrostatically positive $(\delta+v e)$ hydrogen face.

use in pharmaceuticals and agrochemicals discovery programmes.

Compounds 1-3 are unfunctionalised and not amenable to derivatisation, and therefore we started to explore the chemistry of all-cis-3-phenyl-1,2,4,5-tetrafluorocyclohexane (4) [6], to access derivatives carrying this ring motif. In that context it has been demonstrated that $\mathbf{4}$ can be elaborated in a relatively straightforward manner by mainstream reactions of electrophilic aromatic substitution [7]. This extended to the synthesis of cyclohexane substituted (S)-L-phenylalanines with orthogonal protecting groups suitable for their incorporation into peptides [8]. In this paper it is demonstrated that palladium mediated carbonylation of the aryl iodinated derivatives 5-7 forms the basis of a diversity of new products which may prove attractive as building blocks for structure activity studies in bioactive research projects.

\section{Results and Discussion}

A key reaction for this programme involved the carbonylation of aryl iodides 5, 6 and 7 which are derived by $\mathrm{HIO}_{4}$ treatment of all-cis-3-phenyl-1,2,4,5-tetrafluorocyclohexane (4). The ortho isomer 5 was separated from the meta and para isomers 6 and 7, the latter of which were recovered as a mixture as previously reported [8]. Palladium catalysed carboxylation [9] was explored with aryl iodides 5 or $6 / 7$ as a mixture, and these gave the corresponding ethyl esters $\mathbf{8}$ and $\mathbf{9} / \mathbf{1 0}$, respectively. The meta and para esters $\mathbf{9}$ and $\mathbf{1 0}$ were easily separated by chromatography. Hydrolysis of esters $\mathbf{8}-\mathbf{- 1 0}$ using trifluoroacetic acid (TFA) or $6 \mathrm{M} \mathrm{HCl}$ in dioxane [10] gave the corresponding benzoic acids 11, 12, and $\mathbf{1 3}$ as illustrated in Scheme 1.

Direct palladium catalysed formylation of aryl iodides $6 / 7$ as a mixture was explored using $\mathrm{Pd}\left(\mathrm{PPh}_{3}\right)_{4}, \mathrm{Bu}_{4} \mathrm{SnH}$ and $\mathrm{CO}$ [11]. This generated benzaldehyde derivatives $\mathbf{1 4}$ and $\mathbf{1 5}$ in a 1:3

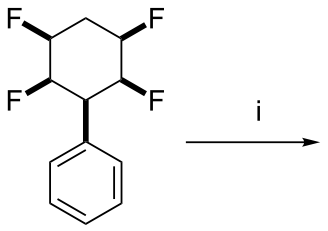

4

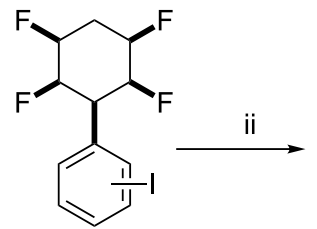

$\begin{array}{ll}5 & \text { ortho } \\ 6 & \text { meta } \\ 7 & \text { para }\end{array}$<smiles>CCOC(=O)c1ccccc1C1C(F)C(F)CC(F)C1F</smiles><smiles>O=C(O)c1cccc(C2C(F)C(F)CC(F)C2F)c1</smiles>

8 ortho $88 \%$

10 para $42 \%$
11 ortho $94 \%$

12 meta 89\%

13 para $90 \%$ 
ratio, respectively, which could be separated by column chromatography. The reaction is illustrated in Scheme 2. The structure of aldehyde $\mathbf{1 5}$ was confirmed by X-ray structure analysis and is shown in Figure 2.<smiles>FC1CC(F)C(F)C(C2=CC=C[CH][IH2]2)C1F</smiles>

$6 / 7$<smiles>O=Cc1cccc(C2C(F)C(F)CC(F)C2F)c1</smiles>

$14(17 \%)$<smiles>O=Cc1ccc(C2C(F)C(F)CC(F)C2F)cc1</smiles>

$15(52 \%)$
Scheme 2: Synthesis of benzaldehyde derivatives 14 and 15 : i. $\mathrm{Pd}\left(\mathrm{PPh}_{3}\right)_{4}, \mathrm{Bu}_{3} \mathrm{SnH}, \mathrm{THF}, \mathrm{CO}(1 \mathrm{~atm}), 50{ }^{\circ} \mathrm{C}, 2-3 \mathrm{~h}, 70 \%$.

Transformations of benzaldehyde $\mathbf{1 5}$ were explored. For example McMurry coupling [12] of $\mathbf{1 5}$ gave a mixture of stilbene isomers 16. Direct hydrogenation of the mixture afford dihydrostilbene $\mathbf{1 7}$ as a crystalline solid, a structure which was confirmed by X-ray crystallography and is shown in the inset in Scheme 3. Aldehyde $\mathbf{1 5}$ could also be converted to styrene $\mathbf{1 8}$ in

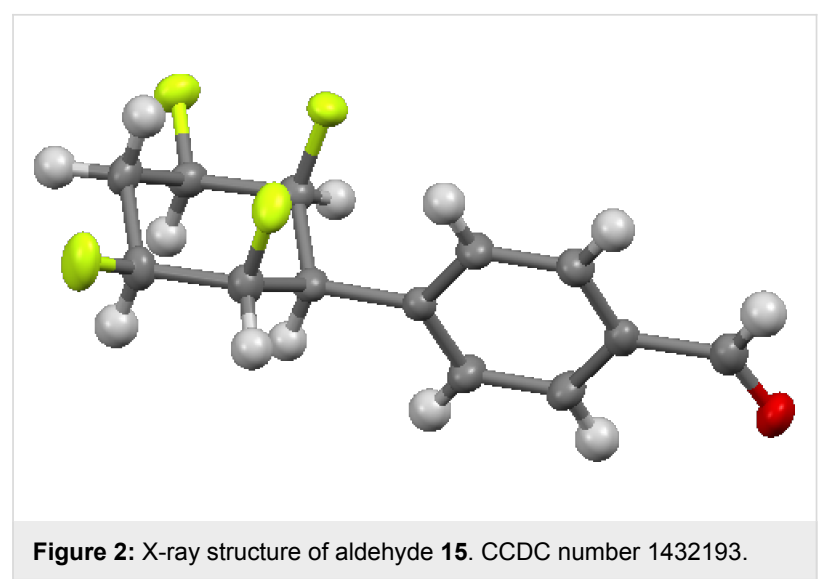

good yield using the Simmons-Smith method [13] as illustrated in Scheme 3.

For further elaboration, aldehyde $\mathbf{1 5}$ was reduced with $\mathrm{NaBH}_{4}$ in good yield to generate the corresponding benzyl alcohol 19 [14]. Iodination of $\mathbf{1 9}$ to generate $\mathbf{2 0}$ with HI in chloroform [15] proved superior (95\% yield) to the more classical Appel protocol which gave low yields in our hands. Nucleophilic substitution with the resultant benzyl iodide $\mathbf{2 0}$ using azide gave the corresponding benzyl azide $\mathbf{2 1}$ in good yield [16]. Chlorination to generate $\mathbf{2 3}$ was accomplished by treatment with mesyl<smiles>CC(C)(C)C(=O)c1ccc(C2C(F)C(F)CC(F)C2F)cc1</smiles>

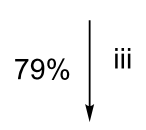<smiles>C=Cc1ccc(C2C(F)C(F)CC(F)C2F)cc1</smiles><smiles>FC1CC(F)C(F)C(c2ccc(C=Cc3ccc(C4C(F)C(F)CC(F)C4F)cc3)cc2)C1F</smiles>

16<smiles></smiles>

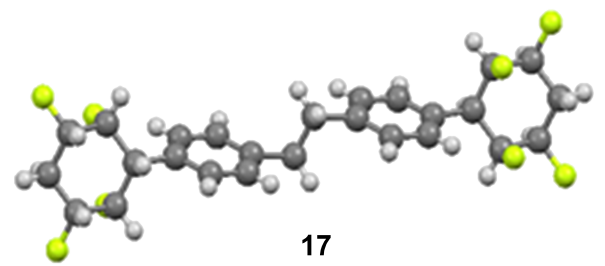

18

Scheme 3: Olefination reactions of 15 and the X-ray structure of 17 (CCDC number 1432194): i. $\mathrm{Zn}, \mathrm{TiCl}_{4}, \mathrm{THF}^{\circ} \mathrm{O}^{\circ} \mathrm{C}$ to reflux, $12 \mathrm{~h}$; ii. $\mathrm{Pd} / \mathrm{C}, \mathrm{H}_{2}$, EtOAc, $20^{\circ} \mathrm{C}, 16 \mathrm{~h}, 76 \%$ over 2 steps. iii. $\mathrm{Zn}, \mathrm{CH}_{2} \mathrm{I}_{2}, \mathrm{TiCl}_{4}, \mathrm{THF}, 0{ }^{\circ} \mathrm{C}$ to $20{ }^{\circ} \mathrm{C}, 12 \mathrm{~h} ; 79 \%$. 
chloride/ $\mathrm{Et}_{3} \mathrm{~N}$ in a one pot protocol, presumably via mesylate 22, as illustrated in Scheme 4 [17].

Reduction of benzyl azide 21 to generate amine $\mathbf{2 7}$ as its hydrochloride salt was achieved by a Staudinger reduction in good yield [18]. Azide 21 was also amenable to a 'click' reaction, in this case with the acetylenic protected amino acid $\mathbf{2 4}$ [19]. This gave the 1,2,3-triazol linked adduct 25 which could be fully deprotected to generate the free amino acid hydrochloride $\mathbf{2 6}$ as illustrated in Scheme 5.
The reactions described above were equally amenable to the meta-benzaldehyde 14, as illustrated in Scheme 6.

\section{Conclusion}

In summary it is demonstrated that the all-cis-1,2,4,5-tetrafluorocyclohexane motif has been incorporated in a range of products prepared from aryl iodides 5-7. These derivatives derive from aryl carboxylation or carbonylation, and complement those that can be prepared directly by electrophilic aromatic substitution of phenyl derivative 4 . This chemistry<smiles>O=Cc1ccc(C2C(F)C(F)CC(F)C2F)cc1</smiles>

15<smiles>CC(C)(C)[Sb](C)(=O)([O-])O</smiles>

19<smiles>CC#CC1C(F)CC(F)C(F)C1c1ccc(CI)cc1</smiles>

20<smiles>N#Cc1ccc(C2C(F)C(F)CC(F)C2F)cc1</smiles>

21<smiles>CCOCc1ccc(C2C(F)C(F)CC(F)C2F)cc1</smiles>

22

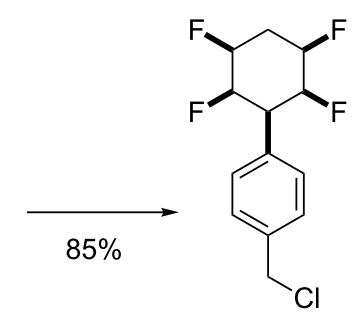

23

Scheme 4: Reactions from aldehyde 15: i. $\mathrm{NaBH}_{4}, \mathrm{THF}, 20^{\circ} \mathrm{C}, 1 \mathrm{~h}, 98 \%$.; ii. $\mathrm{HI}(57 \%), \mathrm{CHCl}_{3}, 30 \mathrm{~h}, 95 \%$; ii. $\mathrm{Bu}_{4} \mathrm{NN}_{3}$, acetone $/ \mathrm{H}_{2} \mathrm{O}(4: 1), 20^{\circ} \mathrm{C}, 3 \mathrm{~h}$, $94 \%$; iv. $\mathrm{MsCl}, \mathrm{Et}_{3} \mathrm{~N}, \mathrm{DCM},-78{ }^{\circ} \mathrm{C}$ to $20^{\circ} \mathrm{C}, 85 \%$.

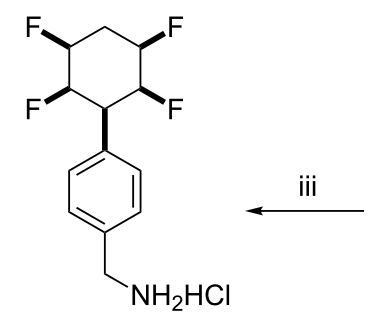

27<smiles>NCc1ccc(C2C(F)C(F)CC(F)C2F)cc1</smiles>

21

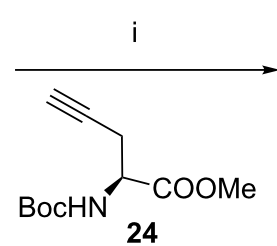

24

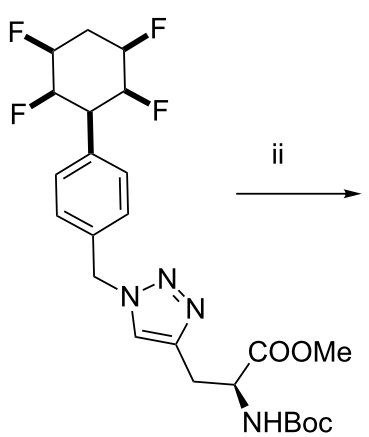

25

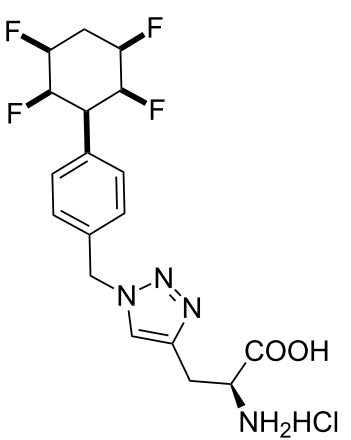

26

Scheme 5: Reactions of benzyl azide 21; i. 24, $\mathrm{Cu}(\mathrm{OAc})_{2}$, Na ascorbate, $t-\mathrm{BuOH}, \mathrm{H}_{2} \mathrm{O}, 20{ }^{\circ} \mathrm{C}, 16 \mathrm{~h}, 72 \%$; ii. $\mathrm{HCl}(6 \mathrm{M}), 1,4-d i o x a n e, 80{ }^{\circ} \mathrm{C}, 48 \mathrm{~h}$, $96 \%$; iii. $\mathrm{Ph}_{3} \mathrm{P}, \mathrm{THF} / \mathrm{H}_{2} \mathrm{O}(10: 1)$, then $\mathrm{HCl}, \mathrm{rt}, 1 \mathrm{~h}, 74 \%$. 


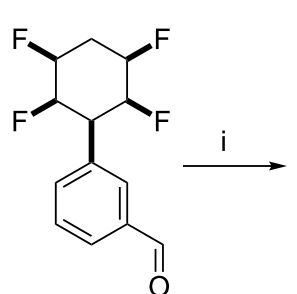

14

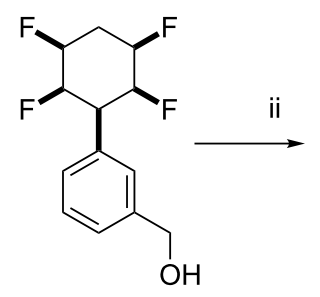

28<smiles>CC#CC</smiles>

29<smiles>NCc1cccc(C2C(F)C(F)CC(F)C2F)c1</smiles>

30

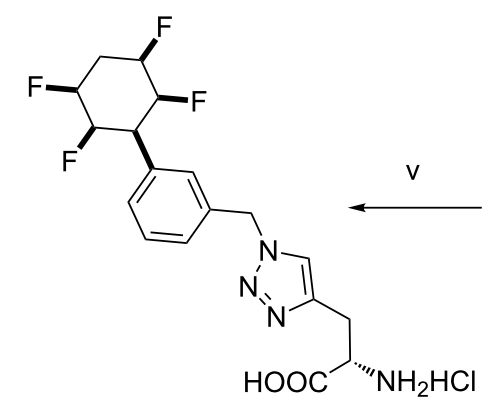

32

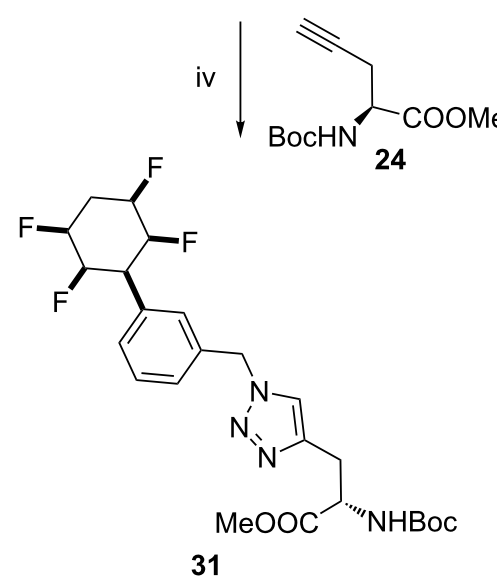

Scheme 6: Reactions of aldehyde 14: i. $\mathrm{NaBH}_{4}$, THF, rt, 1 h, $98 \%$.; ii. $\mathrm{HI}(57 \%), \mathrm{CHCl}_{3}, 30$ h, $94 \%$; iii. $\mathrm{Bu}_{4} \mathrm{NN}_{3}$, acetone/ $\mathrm{H}_{2} \mathrm{O}(4: 1)$, rt, 3 h, $91 \%$; iv. 24 , $\mathrm{Cu}(\mathrm{OAc})_{2}, \mathrm{Na}$ ascorbate, $t-\mathrm{BuOH}, \mathrm{H}_{2} \mathrm{O}, \mathrm{rt}, 12 \mathrm{~h}, 81 \%$; v. $\mathrm{HCl}(6 \mathrm{M}), 1,4$-dioxane, $70^{\circ} \mathrm{C}, 48 \mathrm{~h}, 94 \%$.

should more readily facilitate the exploration of the properties and potential of the all-cis-1,2,4,5-tetrafluorocyclohexane motif in a diversity of research programmes.

\section{Supporting Information}

\section{Supporting Information File 1}

Experimental part.

[http://www.beilstein-journals.org/bjoc/content/ supplementary/1860-5397-11-287-S1.pdf]

\section{Acknowledgements}

MA thanks the Egyptian Government for a Scholarship under the Channel Scheme and we are grateful to the support of Professor L. Fathey of the University of Alexandria, Department of Chemistry, Egypt. DO'H thanks the Royal Society for a Wolfson Research Merit Award and we also thank the EPSRC Mass Spectrometry Service at Swansea University, UK for analyses.

\section{References}

1. Wang, J.; Sánchez-Rosolló, M.; Aceña, J. L.; del Pozo, C.; Sorochinsky, A. E.; Fustero, S.; Soloshonok, V. A.; Liu, H. Chem. Rev. 2014, 114, 2432-2506. doi:10.1021/cr4002879
2. Fujiwara, T.; O'Hagan, D. J. Fluorine Chem. 2014, 167, 16-29. doi:10.1016/j.jluchem.2014.06.014

3. Durie, A. J.; Slawin, A. M. Z.; Lebl, T.; Kirsch, P.; O'Hagan, D. Chem. Commun. 2011, 47, 8265-8267. doi:10.1039/C1CC13016A

4. Durie, A. J.; Slawin, A. M. Z.; Lebl, T.; Kirsch, P.; O'Hagan, D. Chem. Commun. 2012, 48, 9643-9645. doi:10.1039/C2CC34679F

5. Keddie, N. S.; Slawin, A. M. Z.; Lebl, T.; Philp, D.; O'Hagan, D. Nat. Chem. 2015, 7, 483-488. doi:10.1038/nchem.2232

6. Durie, A. J.; Fujiwara, T.; Al-Maharik, N.; Slawin, A. M. Z.; O’Hagan, D. J. Org. Chem. 2014, 79, 8228-8233. doi:10.1021/jo501432x

7. Durie, A. J.; Fujiwara, T.; Cormanich, R.; Bühl, M.; Slawin, A. M. Z.; O'Hagan, D. Chem. - Eur. J. 2014, 20, 6259-6263. doi:10.1002/chem.201400354

8. Ayoup, M. S.; Cordes, D. B.; Slawin, A. M. Z.; O’Hagan, D. Org. Biomol. Chem. 2015, 13, 5621-5624. doi:10.1039/C5OB00650C

9. Moriello, A. S.; Balas, L.; Ligresti, A.; Cascio, M. G.; Durand, T.; Morea, E.; Ortar, G.; Di Marzo, V. J. Med. Chem. 2006, 49, 2320-2332. doi:10.1021/jm051226l

10. Barfoot, C. W.; Harvey, J. E.; Kenworthy, M. N.; Kilburn, J. P.; Ahmed, M.; Taylor, R. J. K. Tetrahedron 2005, 61, 3403-3417. doi:10.1016/j.tet.2004.10.097

11. Baillargeon, V. P.; Stille, J. K. J. Am. Chem. Soc. 1986, 108, 452-461. doi:10.1021/ja00263a015

12. Ruzié, C.; Karpinska, J.; Kennedy, A. R.; Geerts, Y. H. J. Org. Chem. 2013, 78, 7741-7748. doi:10.1021/jo401134c

13. Takai, K.; Hotta, Y.; Oshima, K.; Nozaki, H. Bull. Chem. Soc. Jpn. 1980, 53, 1698-1702. doi:10.1246/bcsj.53.1698

14. Johnson, M. R.; Rickborn, B. J. Org. Chem. 1970, 35, 1041-1045. doi:10.1021/jo00829a039 
15. Bianchini, G.; Aschi, M.; Cavicchio, G.; Crucianelli, M.; Preziuso, S.; Gallina, C.; Nastari, A.; Gavuzzo, E.; Mazza, F. Bioorg. Med. Chem. 2005, 13, 4740-4749. doi:10.1016/j.bmc.2005.04.079

16. Campbell-Verduyn, L. S.; Mirfeizi, L.; Dierckx, R. A.; Elsinga, P. H.; Feringa, B. L. Chem. Commun. 2009, 2139-2141.

doi:10.1039/B822994E

17. Amer, A.; Ayoup, M. S.; Khattab, S. N.; Hassan, S. Y.; Langer, V.; Senior, S.; El-Massry, A. M. Carbohydr. Res. 2010, 345, 2474-2484. doi:10.1016/j.carres.2010.08.010

18. Wallace, K. J.; Hanes, R.; Anslyn, E.; Morey, J.; Kilway, K. V.; Siegel, J. Synthesis 2005, 2080-2083. doi:10.1055/s-2005-869963

19. Kuijpers, B. H. M.; Groothuys, S.; Keereweer, A. R.;

Quaedflieg, P. J. L. M.; Blaauw, R. H.; van Delft, F. L.;

Rutjes, F. P. J. T. Org. Lett. 2004, 6, 3123-3126.

doi:10.1021/ol048841o

\section{License and Terms}

This is an Open Access article under the terms of the Creative Commons Attribution License

(http://creativecommons.org/licenses/by/2.0), which permits unrestricted use, distribution, and reproduction in any medium, provided the original work is properly cited.

The license is subject to the Beilstein Journal of Organic Chemistry terms and conditions:

(http://www.beilstein-journals.org/bjoc)

The definitive version of this article is the electronic one which can be found at: doi:10.3762/bjoc. 11.287 